\title{
Barriers to Career Advancement of Women Managers in Indian Five Star Hotels: A Gender Perspective
}

\author{
Vidya Patwardhan (Corresponding author) \\ Asst. Professor, Selection Grade, Welcomgroup Graduate School of Hotel Administration \\ (WGSHA), Manipal University, Manipal-576104, Karnataka, India \\ E-mail: vidya.patwardhan@manipal.edu

\begin{abstract}
Suresh Mayya
Associate Professor, Dept. of Commerce, Mahatma Gandhi Memorial College

Udupi - 576101, Karnataka, India

E-mail: sureshmayya@hotmail.com
\end{abstract}

H.G. Joshi

Professor, Department of Commerce, Manipal University, Manipal-576104, Karnataka, India

E-mail: hg.joshi@manipal.edu

Received: May 03, 2016 Accepted: June 18, 2016 Published: July 10, 2016

doi:10.5296/ijhrs.v6i2.9720 URL: http://dx.doi.org/10.5296/ijhrs.v6i2.9720

\begin{abstract}
This descriptive study was carried out to understand the issues related to women managers' career advancement from the perspectives of male managers as represented by general managers and human resource managers of Indian five star hotels. The male managers opined that attitude, leadership skills and communications skills are most important for women to advance in their careers. Factor and regression analyses revealed the relationships between the dimensions of mobility pathway (gender stereotyping, social structure and culture, gender inequality, gaining social capital, and double bind) and human resource strategies adopted by the hotel organizations to support the career advancement of women managers. According to male managers, the utmost barriers to women managers' ascent to leadership positions in Indian five star hotels are: 'more family responsibilities than men', 'lack of flexible work solutions', and 'stereotypes against women'. The findings of this study will be useful for
\end{abstract}


women managers who desire advancement to executive positions and to organizational leaders who wish to hire and promote the right person regardless of gender.

Keywords: Women, Hotels, India, Career Advancement, Gender

\section{Introduction}

\subsection{Women in Workforce}

The process of globalization and liberalization heralded a change in the scenario wherein not only more women join professional courses, but also groomed to become excellent professionals. Due to the change in socio-cultural set up, parents have realized the need for educating their daughters and supported them to have a successful career. The socio-cultural barriers that existed earlier have been turned into an advantage today. Since Indian culture is more family oriented and less-individualistic, women enjoy a safety net that may not be available to their western counterparts. The extended family and the underlying mutual assistance made it easier for women to achieve a work-family balance. Moreover, a unique trend can be noticed in middle-income families, where parents focus on their daughters' education and are willing to make great personal sacrifices to enable them to succeed. Women themselves are becoming more aware of their personal needs and are demanding greater equality and status both at home and outside (Nath, 2000). Given the changes in the attitudes of women in the major Asian countries, an increasing number of women are delaying marriage and motherhood, which may enable to have a greater representation of women in the upper echelons in the years ahead("The flight from marriage," 2011).

\subsection{Women at the Board Level}

As per NDTV Business (2014) report, compared to the global average of $20 \%$, only five percent of working women in India make it to senior leadership positions in the corporate sector. The study revealed that in India, women's strength in the labor force stands at $28 \%$ at the junior level, $14.91 \%$ at the middle level and $9.32 \%$ at the senior level. Nevertheless, as stated in Grant Thornton's International Business Report (IBR), the number of women in senior management went up to 19\% in 2013 from 14\% in 2012 and fell to $14 \%$ again in 2014 . As per 2014 report, globally $24 \%$ of the senior management positions were occupied by women with China at 38\%, Eastern Europe at $37 \%$ and South East Asia at 35\%. The same report also mentioned that globally $35 \%$ employees were women; however, in India the proportion is significantly low at $15 \%$.

\subsection{Women in Hospitality}

Although the number of women entering the hospitality industry is consistent and moderately increasing in India, women at the managerial level appear to be leaving the industry at a higher rate than their male counterparts. Surprisingly, the male female ratio at the managerial level is approximately 5:1 to begin with at lower levels of management but there is no corresponding increase in the number of women in top management positions (HVS, 2014). A few women who attain the executive positions occupy staff roles, particularly in 
departments like sales and marketing and human resources. According to HVS survey, the percentage of women is higher in five star deluxe and five star hotels at all levels including managers, supervisors and staff. It shrinks in lesser category hotels and the all India women general manager average is $2-3 \%$ across categories (Chaudhary\& Gupta, 2010).

\subsection{Glass Ceiling}

The field of hospitality is male dominated at higher levels and shrinking number of women continuing career in the industry negatively affect the number of women at high levels. In India, many women from hotel industry who are in mid-career are leaving hotel jobs, opting for a career in small businesses like restaurants, bakery and confectionary or work as consultants (Patwardhan, 2012). Institutional barriers and social attitudes towards women's abilities hamper the movement of women to the higher echelons of management and they may be struggling to reach the top positions in the hospitality industry because of multiple commitments. (Ng \& Pine, 2003; Zhong, 2006; Baum 2013). Existence of segregation in the hospitality sector may have forced women to have jobs with lower status (Kattara, 2005). Due to gender socialization and social expectation there will be a role conflict for women and at the same time the culture of hospitality is quite demanding due to irregular working hours and pressures of work (Ng \& Pine, 2003; Zhong, 2006; Kumar, 2014). This perception of lack of commitment by women compounds with gender discrimination (Burke, 2006) results in more women concentration towards 'non-strategic jobs' rather than line and management jobs (Ng \& Pine, 2003). Along with organizational barriers such as perception of feminine traits, in-hospitable culture and lack of networking, self-imposed barriers have also been noticed by researchers (Boone, 2013). Moreover, the scarcity of female mentors and sponsors makes it more difficult for women to have access to mentors (Adams, 2004; Apospori, et al. 2006, Neil, 2007).

In India, prior research that focuses on women's career advancement is infrequent, with some notable exceptions (Chaudhary\& Gupta, 2010; Chaudhary \& Gupta, 2011; CSR, 2010; Singh, 2011; Panwar, 2012; Subramanian, 2014). Women remain under-represented in upper ranks in hotel industry; nevertheless, diminutive research has been made to study the characteristics of career advancement of women in hotel industry in Indian hotels. The key question here - Is hotel industry a place of opportunity for aspiring women managers or is it an inequality regime dominated by male managers? Keeping these crucial aspects in mind, the purpose of this study was to find out the perspectives of male managers regarding the career advancement of women managers in Indian five star hotels. In doing so, we discuss the effectieness of organizational initiatives through various human resource strategies and the significant barriers to women's career advancement. The findings should shed some light on how to better tap women's potential to the benefit of the expanding Indian hotel industry.

\section{Literature Review}

\subsection{Contributing Factors to Career Advancement of Women Managers}

As Gregg and Johnson (1990) note, women and men with similar educational backgrounds and producing similar products do have different work related experiences (Brownell, 1994). 
Career advancement in the corporate world is always a joint endeavor between the employee and the organization. In most of the cases promotion to an executive position isinterplay between the executive's competence, efforts and the organizations support and encouragement (Omotayo, et al. 2014). Men and women use different strategies to excel and rise to the top. The most important strategy women adopt is to exceed expectations (Knutson, B.J., 1999). The corollary strategies may be seeking out high visibility assignments (Catalyst, 2012), responsible for a large workforce, accepting complicated assignments, trying to gain management experience (Nzioka, 2013), working in cross functional areas (Burke \& Nelson, 2002), having an influential mentor (Burke\& Nelson, 2002), relocating (as cited in Clerk, 2014), changing jobs and companies, effective inter personal skills, and communicating effectively (Brownell, 1999) and not the least developing a style with which men are comfortable (Ladkin, 2002).

According to Burke (2002), education, training and development can be conceived of as being either or both challenge and support. The existence of organization support systems (Culpan\& Wright, 2002), mentoring (Mattis, 2002; Allen \&Ebby, 2002), networking (Wirth, 2001), training and development programs (Loutfi, 2001; Wirth, 2001), and organization cultures that support women (Bajdo\&Dickson, 2001) have been found to be very important for women's advancement to management positions. But the career paths between men and women are different and men make more career moves and have more management positions before attaining general manager's position (Blayney\&Blotnicky, 2010). Women need to develop adaptive strategies by which they actively construct and modify their roles, resources and relationships to offset problems and derive benefits from these multiple roles (Ezzedeen, 2009).

\subsection{Factors Affecting Career Advancement - Career Experiences}

Women manager's profile and challenges have been the concern of several studies since decades (Brownell, 1993; Woods \&Viehland;2000, Li, 2001; Ng\& Pine, 2003; Kattara, 2005; Mooney, 2007;Tlaiss\&Kauser, 2010; Sposito, 2013). Barriers were postulated as a construct to describe the gap between women's abilities and their achievements or to explain the inhibitions of women's career ambitions (Swanson \&Woitke, 1997). Barriers arise from a variety of origins, including internal, external and interactional sources (Swanson \&Toker, 1991). According to Powell (2000) barriers fall into two categories: 1. Person centered includes personality traits, lack of certain key skills and behaviors as against the demands of managerial roles. 2. Situation centered - barriers found within the work and socio-cultural environment. The argument here is alternatively, women may prioritize work life balance and job satisfaction over the 'male' notions of career success. Boone (2013) advocates that barriers to women career advancement might be undergoing a shift from traditional work force barriers to self-imposed barriers, the most common being family and household responsibilities holding a higher priority as well as work-life balance. Although these findings were tested within American and European contexts, they do give a broader picture of the status of women in management in India when compared with various reports (Catalyst, 2014, HVS, 2014: NDTV, 2015). 


\section{Methodology}

The purpose of this study was to determine the perceived barriers to career advancement of women managers from the perspective of selected male managers (GM, HR, and Training Manager). The review of literature pertaining to career advancement and career barriers to women managers helped the researcher to discover the possible barriers to career advancement of women managers and the challenges encountered by them from the organizational perspective as represented by male managers. Key themes were drawn from the relevant literature and the researcher's personal communication with industry expertswere explored in a quantitative survey. 92 male managers from 46 five star hotels in the cities of Delhi, Gurgaon, Mumbai, Pune, Chennai and Bangalore participated in the study. Between November 2014 and April 2015 the researcher visited these hotels to collect the data. At the time of the study there were 101 five star luxury hotels in India spread across seventeen cities (fivestaralliance.com). Of the 46 hotels chosen for the study, the male-female ratio was 1 : 0.35 (1693 male managers and 572 female managers). The components of the questionnaire included demographic profile, policies and preferences regarding recruitment of women in these hotels, contributing factors, twelve important statements associated with presence or absence of company strategies/initiatives related to women's career advancement, thirtyfive variables related to factors affecting women's career advancement and fifteen variables related to significant barriers. The questionnaire was based on similar studies by Brownell (1994) and Ng and Pine (2003) and ILO report (2015).

\section{Analysis and Discussion}

\subsection{Demographic details}

The descriptive analysis unveiled that among the 92 male managers participated in the study, $61 \%$ of them have earned post graduate degrees.62\% of the managers have less than five years of service with the current employer and $21.5 \%$ of them have service between six and ten years and $16.5 \%$ managers have the longest service of 16-20 years with the same organization. The number of hours worked in a week ranged from 45 hours to more than 70 hours with an average of around 60 hours per week. Majority of the respondents $(61.1 \%)$ worked up to 56 to 60 hours a week. As per the norms of the Indian hospitality industry the average work week is 54 hours and none of the male managers are privileged to leave hotel as prescribed in HR policy framework.

Sixty one percent of the respondents mentioned that their hotel companies do not have any policy/guidelines regarding male-female ratio. Unanimously all participant male managers mentioned that they give equal preference to all categories of women. They do not show any discrimination based on marriage, while hiring and promoting women managers. Sixty seven percent of the managers mentioned that they have a re-hiring policy in their hotels and $11 \%$ of the managers mentioned that it happens on case to case basis, which means that in spite of not having any uniform policies, they do consider re-hiring. In India the new Companies bill passed on August 8, 2013 which provides at least one woman on the boards of the listed companies, there is still a debate about whether quotas should be introduced (Menon, 2013). The reputed international hotel chains like Accor for example, have started 
Accor groups' diversity charter which is based on the principle of non-discrimination and equal treatment. They have an internal networking program called WAAG (Women at Accor Generation) emphasizing women's roles and opportunities at Accor. The WAAG committees have established country specific tailored activities and programs to meet the unique challenges faced by women (Baum, 2015). Hilton worldwide is trying to close the gender gap by launching programs to prepare and employ young people of both sexes around the world by 2019 (Clerk, 2014). In India one of the leading hotel chain ITC is now laying the red carpet for women professionals, fasttracking their career growth and building a pipeline of candidates who can take on senior management roles. ITC wants to double the proportion of women employees to $30 \%$ from the current $16 \%$ (ITC to double proportion of women employees to 30 pc., 2013).

\subsection{Career Success Indicators}

The table 1 presents the general perception of male managers concerning socio-cultural and organizational factors affecting women's career advancement in the hospitality industry.

Table 1: Career success indicators

\begin{tabular}{|l|c|c|}
\hline Career success indicators & Mean & Rank \\
\hline Attitude & 4.72 & I \\
\hline Personality & 4.00 & VII \\
\hline Communication skills & 4.28 & III \\
\hline Leadership skills & 4.44 & II \\
\hline Ability to create their identity & 4.00 & VII \\
\hline Job knowledge & 4.22 & IV \\
\hline Managerial skills & 4.17 & V \\
\hline Coaching \& Mentoring support & 3.94 & VIII \\
\hline Networking opportunities & 3.33 & X \\
\hline Family support & 4.22 & IV \\
\hline Mobility & 4.06 & VI \\
\hline Work environment & VII \\
\hline
\end{tabular}




\begin{tabular}{|l|c|c|}
\hline Political savvy & 2.72 & XI \\
\hline Proactiveness & 4.17 & V \\
\hline Support systems at work & 3.89 & IX \\
\hline
\end{tabular}

Individual qualities such as (attitude, leadership skills, communication skills, job knowledge, proactiveness, personality, ability to create identity), and the accumulation of human capital and social capital (managerial skills, mobility, coaching and mentoring, work environment) are the necessary requirements for any manager regardless of gender. They reflect catalyst (2014), Mckinsey (2014) and ILO (2015) report's findings that women's career strategies are associated with individual rather than organizational factors. Broadbridge (2008) in a study on male and female senior retail managers observed that determination, attitude, interpersonal skills, performance are most important among the 45 factors identified and networking, role models and mentoring are factors that men were less likely to regard as assisting women's careers which coincides with the results of this study. A doctoral study by Nzioka (2013) on general manager's perception of career advancement of women managers in Kenya hotels found that attitude, educational qualifications, career goals and personality were the most important personal factors affecting career advancement of women managers. Chen (2011) in a study on hotel manager's job satisfaction found out that women's career was mainly affected by personal factors such as personality, physical traits, capability and family, and also organizational structure and social culture. The top five career advancement indicators as per the results of this study matches with the research findings of existing studies on career advancement.

\subsection{Presence and absence of company strategies related to women's career advancement}

Most of the Indian five star hotels have taken initiatives to address the exclusive needs of women managers as reported by the managers during the discussion. The presence and absence of certain strategies is presented below. Along with the percentages, the order of presence or absence is also indicated. Order I is most extant and order VII is least extant as per the facts reported by the male managers.

Table 2: Presence of absence of company strategies/Initiatives

\begin{tabular}{|c|l|l|l|c|}
\hline $\begin{array}{c}\text { S1 } \\
\text { No }\end{array}$ & Company strategies/initiatives & $\begin{array}{l}\text { Present } \\
\text { No } \\
\text { and } \%\end{array}$ & $\begin{array}{l}\text { Absent } \\
\text { \&o } \%\end{array}$ & Order \\
\hline 1 & Women's network within the company & $\begin{array}{l}24 \\
(44.4)\end{array}$ & $\begin{array}{l}30 \\
(55.6)\end{array}$ & VI \\
\hline 2 & Formal mentoring programs for women & 33 & 21 & $\mathrm{~V}$ \\
\hline
\end{tabular}




\begin{tabular}{|c|c|c|c|c|}
\hline & & $(61.1)$ & $(38.9)$ & \\
\hline 3 & $\begin{array}{l}\text { Identification \& fast-tracking of high } \\
\text { potential women }\end{array}$ & $\begin{array}{l}39 \\
(72.2)\end{array}$ & $\begin{array}{l}15 \\
(27.8)\end{array}$ & III \\
\hline 4 & Job rotation programs & $\begin{array}{l}36 \\
(66.7)\end{array}$ & $\begin{array}{l}18 \\
(33.3)\end{array}$ & IV \\
\hline 5 & $\begin{array}{l}\text { Inclusion of women in company leadership } \\
\text { programs }\end{array}$ & $\begin{array}{l}51 \\
(94.4)\end{array}$ & $3(5.6)$ & II \\
\hline 6 & $\begin{array}{l}\text { Provision of high visibility assignments for } \\
\text { women }\end{array}$ & $\begin{array}{l}42 \\
(77.8)\end{array}$ & $\begin{array}{l}12 \\
(22.2)\end{array}$ & II \\
\hline 7 & $\begin{array}{l}\text { Provision of career related executive } \\
\text { development programs }\end{array}$ & $\begin{array}{l}54 \\
(100)\end{array}$ & $0(0)$ & I \\
\hline 8 & $\begin{array}{l}\text { Provision of family friendly employment } \\
\text { policies }\end{array}$ & $\begin{array}{l}39 \\
(72.2)\end{array}$ & $\begin{array}{l}15 \\
(27.8)\end{array}$ & III \\
\hline 9 & $\begin{array}{l}\text { Flexible work policies and programs } \\
\text { specific to women }\end{array}$ & $\begin{array}{l}18 \\
(33.3)\end{array}$ & $\begin{array}{l}36 \\
(66.7)\end{array}$ & VII \\
\hline 10 & $\begin{array}{l}\text { Provision of equal employment } \\
\text { opportunities }\end{array}$ & $\begin{array}{l}51 \\
(94.4)\end{array}$ & $3(5.6)$ & II \\
\hline 11 & Child care facilities & $\begin{array}{l}24 \\
(44.4)\end{array}$ & $\begin{array}{l}30 \\
(55.6)\end{array}$ & VI \\
\hline 12 & Periodic career development reviews & $\begin{array}{l}54 \\
(100)\end{array}$ & $0(0)$ & I \\
\hline
\end{tabular}

The implementation of policy frameworks regarding career related executive development programs, periodic career development reviews, inclusion of women in company leadership programs, and provision of equal employment opportunities by the hotel companies are commendable. The most ignored aspects as per the study results related to participating hotels, is the absence of flexible work policies and programs specific to women, child care facilities, and women's networks. Among these three facets, flexible work policies and child care facilities are most important for women due the additional life role responsibilities. The fundamental nature and characteristics of the hotel industry does not allow managers to leave the hotel premises as per the scheduled duty hours. Broadbridge (2008) in a study on senior retail managers remarks that, even though many retail companies claim special provisions for women such aschild care, career break options and flexible working hours, it is only a lip 
service to such provisions. Centre for social research on women managers in India notes that, none of the Indian hospitality companies have gender policy but women reported that their companies are gender sensitive. Support systems such as medical facilities and transport facilities are quite satisfactory where as flexible hours and crèches for children are offered by only $3.5 \%$ of the hotel companies. Several researchers have proposed suggestions towards implementation of policy measures to take care of these special needs of women (Doherty, 2004; Mooney, 2007; Boone, 2013; Baum, 2013; Baum, 2015)

Interestingly, the ILO (2015) report regarding implementation of 20 company policy measures shows more or less similar results, where maternity leave topped the list followed by access to skills training and elder care was the least among the 20 policy measures. Catalyst (2013) asks an important question - "Whether we work to live?? Or to we live to work??" In this report they provide examples from leading organizations 'flexibility in action' to help the corporate world to implement flexibility within their organizations.

4.4 Gender specific opinions/perceptions of factors affecting women's career advancement: Results of factor analysis

This section of the questionnaire contained 35 statements specific to the differences observed during the review of literature and interaction with hotel industry personnel regarding career barriers and enablers. They include items related to career advancement, management attitudes, work environment, challenges, organizational barriers and personal barriers to career advancement of women managers. Among the 35 variables, 23 variables are negative statements addressing the problems faced by women managers. They include personal, organizational (glass ceiling, work hours, pay package, promotional opportunities, old boy network, corporate culture, social exclusion, stereotyping, gender issues), societal, and environmental barriers. 12 variables are positive statements that include the individual capabilities, gender equality, support systems - both organizational and personal, and supportive work culture. The 23 negative statements of the data set were re-coded after the data entry process to make the scale consistent. For the purpose of factor analysis, the reversed data set was used.

These items were analyzed by using principal components factor analysis with varimax rotation. From the final analysis the items which failed to load at 0.40 on a single factor were excluded. Comrey \& Lee (1992) suggested that loadings in excess of 0.71 (50\% overlapping variance) are considered excellent, 0.63 (40\% overlapping variance) are considered very good, 0.55 (30 per cent overlapping variance) are considered good and 0.45 (20\% overlapping variance) are considered fair. The results show that all the variable loading reached this acceptable standard. The factor analysis extracted five factors (34 items) with item loadings ranging from 0.409 to 0.932 . 
Table 3: KMO and Bartlett's test

\begin{tabular}{|l|c|c|c|c|}
\hline \multicolumn{2}{|c|}{ Kaiser-Meyer-Olkin (KMO) and Bartlett's test result } \\
\hline \multicolumn{2}{|c|}{ Bartlett } & KMO & Chi-square(df) & Sig. \\
\hline Gender Stereotyping & 357.456 & 0.710 & 36 & .001 \\
\hline $\begin{array}{l}\text { Social Structure and } \\
\text { Culture }\end{array}$ & 231.96 & 0.669 & 28 & .001 \\
\hline Gender Inequality & 120.986 & 0706 & 21 & .001 \\
\hline Gaining Social Capital & 83.758 & 0.713 & 10 & .001 \\
\hline Double Bind & 86.142 & 0.672 & 10 & .001 \\
\hline
\end{tabular}

The data is appropriate for factor analysis as the results of the Bartlett's test is significant and the KMO value is more than 0.50 for all variables as required. The chi-square of the variables in each set is significant at $\mathrm{p}=.001$, and the KMO statistics ranged from 0.669 to 0.710 , indicating that the data are appropriate for factor analysis.

Table 4a: Gender stereotyping

\begin{tabular}{|c|c|c|c|c|c|}
\hline $\begin{array}{l}\text { Factor } \\
\text { and name }\end{array}$ & Components & $\begin{array}{l}\text { Alpha } \\
\text { level }\end{array}$ & $\begin{array}{l}\text { Variables } \\
\text { retained }\end{array}$ & $\begin{array}{l}\text { Variables } \\
\text { removed }\end{array}$ & Loading \\
\hline & & 0.804 & 09 & 0 & \\
\hline & \multicolumn{4}{|c|}{ Lower professional capabilities \& career commitment } & 0.959 \\
\hline & \multicolumn{4}{|c|}{ Promotion process is fair and gender neutral } & 0.803 \\
\hline & \multicolumn{4}{|c|}{ Being a female in itself is a barrier for growth } & 0.793 \\
\hline & \multicolumn{4}{|c|}{ Cost of hiring women is more than men } & 0.740 \\
\hline & \multicolumn{4}{|c|}{ Women's inability to cope up with pressures of long hours } & 0.710 \\
\hline & \multicolumn{4}{|c|}{ Men and women are given equal opportunities } & 0.707 \\
\hline $\begin{array}{l}\text { Factor } 1 \\
\text { - Gender }\end{array}$ & \multicolumn{4}{|c|}{ Difficulty to get into right networks and sponsorship relations } & 0.670 \\
\hline Stereotyp & \multicolumn{4}{|c|}{ Personal qualities required are different for men and women } & 0.662 \\
\hline
\end{tabular}




\begin{tabular}{|l|lc|}
\hline ing & Women are excluded from social events & 0.541 \\
\hline
\end{tabular}

Table 4b: Social structure and culture

\begin{tabular}{|c|c|c|c|c|c|c|}
\hline $\begin{array}{l}\text { Factor } \\
\text { and } \\
\text { name }\end{array}$ & Components & $\begin{array}{l}\text { Alpha } \\
\text { level }\end{array}$ & $\begin{array}{l}\text { Variables } \\
\text { retained }\end{array}$ & $\begin{array}{l}\text { Variables } \\
\text { removed }\end{array}$ & & oading \\
\hline \multirow{5}{*}{$\begin{array}{l}\text { Factor } 2 \\
\text { - Social } \\
\text { Structure }\end{array}$} & & 0.872 & 08 & 0 & & \\
\hline & \multicolumn{4}{|c|}{ Women are required to imitate male traits to develop careers } & & 0.821 \\
\hline & \multicolumn{4}{|c|}{ Women's democratic inclusive style is not effective } & & 0.790 \\
\hline & \multicolumn{4}{|c|}{ Organizational culture is in alignment with men's styles } & & 0.777 \\
\hline & \multicolumn{4}{|c|}{ Women with children are perceived as liability } & & 0.728 \\
\hline $\boldsymbol{\&}$ & \multicolumn{4}{|c|}{ Women are not given challenging tasks and visible assignments } & & 0.706 \\
\hline & \multicolumn{4}{|c|}{ Structures in hotels seem to favour promotion of male manager } & & 0.683 \\
\hline & \multicolumn{4}{|c|}{ Women receive enough support to manage dual responsibilities } & & 0.557 \\
\hline & \multicolumn{4}{|c|}{ Difference in leadership skill requirement between men and $v$} & hen & 0.501 \\
\hline
\end{tabular}

Table 4c: Gender inequality

\begin{tabular}{|l|l|c|c|c|c|}
\hline $\begin{array}{l}\text { Factor and } \\
\text { name }\end{array}$ & \multicolumn{1}{|c|}{ Components } & $\begin{array}{c}\text { Alpha } \\
\text { level }\end{array}$ & $\begin{array}{c}\text { Variables } \\
\text { retained }\end{array}$ & $\begin{array}{c}\text { Variables } \\
\text { removed }\end{array}$ & Loading \\
\hline & 0.700 & 07 & 0 & \\
\cline { 2 - 5 } & Women have lower professional capabilities and commitments & 0.844 \\
Factor 3 - & Lack of Mobility becomes a barrier to development & 0.811 \\
Gender & Rate of attrition in management positions is higher among women & 0.765 \\
& Gender discrimination still exists subtly & 0.752 \\
& Women are ambitious, competitive and outgoing & 0.578 \\
& Women are natural networkers and terrific communicators & 0.499 \\
& Women face more obstacles to advancement than men & 0.494 \\
\hline
\end{tabular}


Table 4d: Gaining social capital

\begin{tabular}{|l|l|c|c|c|c|}
\hline $\begin{array}{l}\text { Factor } \\
\text { and } \\
\text { name }\end{array}$ & Components & $\begin{array}{c}\text { Alpha } \\
\text { level }\end{array}$ & $\begin{array}{c}\text { Variables } \\
\text { retained }\end{array}$ & $\begin{array}{c}\text { Variables } \\
\text { removed }\end{array}$ & Loading \\
\hline & 0.808 & 06 & 0 & 0.722 \\
\cline { 2 - 5 } & Women have to work twice harder and perform better & 0.680 \\
Factor & Women's self-imposed barriers are reinforced in organizations & 0.649 \\
Gaining & Absence of women at the top makes progress difficult & 0.607 \\
Social & Men and women receive same level of rewards & 0.590 \\
Capital & Men exclude women from informal networks & 0.576 \\
\hline
\end{tabular}

Table 4e: Double bind

\begin{tabular}{|l|c|c|c|c|c|}
\hline $\begin{array}{l}\text { Factor } \\
\text { and } \\
\text { name }\end{array}$ & Components & $\begin{array}{c}\text { Alpha } \\
\text { level }\end{array}$ & $\begin{array}{c}\text { Variables } \\
\text { retained }\end{array}$ & $\begin{array}{c}\text { Variables } \\
\text { removed }\end{array}$ & Loading \\
\hline & 0.701 & 05 & 0 & 0.826 \\
\cline { 2 - 5 } & \multicolumn{2}{l}{ Women managers are emotional } & 0.760 \\
\multirow{2}{*}{$\begin{array}{l}\text { Factor } \\
\text { Double }\end{array}$} & \multicolumn{2}{l}{ Women are timid in their managerial styles } & 0.734 \\
Bind & Invisible artificial barriers blocks women's growth & 0.659 \\
\hline
\end{tabular}

Based on the meaning and compatibility of variables the category names are provided by the researcher. Some of the category names (e.g. double bind) were chosen from a Harvard Business School book "Through the Labyrinth" by Eagly andCarli (2007). The contribution from this research to the existing base of knowledge lies in the new patterns observed through the outcomes of this study. The existing literature from 1990 to date has a set pattern of groupings as well as factors (Brownell, 1993; Brownell, 1994; Li, 2001; Kattara, 2005; Zhong, 2006; Broadbridge, 2008; Mooney, 2007; CSR, 2010; Boone, 2013; Clerk, 2014) which varied with the results of this study. 


\subsubsection{Factor 1: Gender stereotyping}

The first dimension, which the researcher termed as "gender stereotyping" consists of items related to certain facets such as: professional capabilities, being a woman, woman and higher costs, personal qualities, equal opportunities, and women's inability to take work pressure. Nine items were identified under factor one with factor loadings ranging from 0.541 to 0.959 .

These are negative assumptions to executive ranks about women and their commitment to careers. The gender role influence and moderate career advancement potential due to stereotypical assumptions and views about women's abilities continues to create barriers for women's career progression. A novel reason to expect changing gender stereotypes in organizations is due to increased focus on diversity. To increase awareness and appreciation of differences between individuals and to decrease stereotypes held by organizations diversity training programs have been designed by many organizations (Duehr, 2006). Many men today have been raised in dual income or single parent home which allow them see women from a different perspective than men from previous generations. These changes in cultural and societal norms have led to a waning in traditional masculine and feminine gender role perceptions that existed decades ago (Coder, 2013). Hopefully, Indian hotels are going to experience the same in the near future, due to the presence of international hotel chains in India.

\subsubsection{Factor 2: Social structure \& culture}

The second dimension is termed as "social structure and culture" that include items such as: imitating male traits, women's democratic style of management, culture in alignment with men's style; women with children are liabilities, lack of visible assignments, structural favors toward men and organizational support. Eight items were identified under factor two with factor loadings ranging from 0.501 to 0.821 .

The disruptions and breakdowns are more in women's careers due to relationships outside jobs that create a barrier for career planning and advancement. They face fundamentally different experiences, priorities and options in their social and organizational roles compared to men due to societal expectations, marital status, motherhood, family constraints and career demands. Unfortunately these factors are still prevalent in India and have an influence on women in most of our cultures and there is a subtle influence of this on the work life of women. The sex role stereotyping where people associate male characteristics and men with leadership positions, the so called "think leader, think male" phenomenon becomes instrumental in increasing this work place social problem.

\subsubsection{Factor 3: Gender inequality}

The third dimension is named as "gender inequality" that includes: differential treatment toward women, gender discrimination, women's inability to move, high rate of attrition, personal qualities and women's networking abilities. Seven items were identified under this factor with factor loadings ranging from 0.494 to 0.844 .

There are visible changes in the corporate world through enactment of various policies and 
procedures both at the government and at the private sphere, but equality is not achieved completely as men and women are not represented equally at senior management levels. Women have to work twice as hard as their male colleagues to achieve recognition (Wirth, 2001). Al though large number of women enter work force at similar levels as their male counterparts, their career progresses more slowly than their male colleagues.Harvard University research by Carter and Silva (2010) highlights the disappointing truth about women lagging behind in spite of aggressive efforts to create opportunities for women, inequities remain entrenched.

\subsubsection{Factor 4: Gaining social capital}

The fourth dimension termed as "gaining social capital", that related to women working harder than men, women's self-imposed barriers, and absence of women at the top, same level of rewards and women in non-strategic jobs. Six items were identified under Factor four with factor loadings ranging from 0.576 to 0.722 .

Managers usually spend considerable time in informal interactions that are essential to build knowledge, trust, and cooperation and shared understanding. Sometimes gender affects social capital and women miss the dynamics of these relationships. The advantages of informal networking and mentoring relationships have been cited by many researchers (Adams, 2004; Kattara, 2005; Apospori, et al. 2006; Linehan\& Scullion, 2008; Ibbara, et al., 2010; Walsh, et al. 2014) and the perception that women are not as effectively networked as men reflects causes other than their lack of ability to do so.

\subsubsection{Factor 5: Double bind}

Factor five is termed as "double bind" which includes aspects of their timid managerial styles, emotional, organizational prejudices, working style, and mentoring programs. Five items were identified under this factor with factor loadings ranging from 0.547 to 0.826 .

As explicated by Eagly\&Carli (2007), people associate men with authoritarian roles in which they display assertive and self-confident behaviors. Women are considered as communal who is expected to be warm and helpful. As a result men become linked with agentic traits and women make no overt attempts to influence others which create a double bind for women. Women have to develop working styles that suits their superiors otherwise they risk not getting a job or promotion when they are too direct. The empirical research evidences strengthen this notion where we associate successful leaders with stereotypically male characteristics such as assertiveness, aggressiveness, independence and decisiveness. Supporting this notion, another factor contributing to the underrepresentation of women in high positions, is that the positions in senior management hold less interest for women than men (Powell, 1999). Women are less likely to enter the contest mobility tournaments leading toward senior management careers due to their low aspirations (Miller, et al, 2005).

Through factor analysis the discrete dimensions of gender specific opinions regarding factors affecting the career advancement of women managers in five star hotels were brought out. In order to understand the intersection of these factors with the policies and strategies adopted by the hotels to address the special concerns of women, regression analysis was undertaken. 


\section{Ml Macrothink}

International Journal of Human Resource Studies

ISSN 2162-3058

2016, Vol. 6, No. 2

Efforts were made to identify the relationship between the career success factors as identified by the male managers and the newly identified factors.

4.5 Regression Analysis with Company Strategies as a Dependent Variable

Table 5: Multiple regression analysis $(\mathrm{N}=92)$

$\mathrm{R}$ square $=.674$

$\mathrm{F}=24.236$

$\mathrm{p}=0.003 * *$

\begin{tabular}{|l|l|c|}
\hline Independent variables & Beta weight & Significance \\
\hline Gender stereotyping & 0.112 & 0.461 \\
\hline Social structure and culture & -0.451 & $0.002^{* *}$ \\
\hline Gender inequality & 0.466 & $0.021^{* *}$ \\
\hline Gaining social capital & 0.411 & $0.022^{* *}$ \\
\hline Double bind & -0.100 & 0.493 \\
\hline
\end{tabular}

Predictors: Gender stereotyping, Social structure \& culture, Gender inequality, Gaining social capital \& Double bind

Dependent variable: Company strategies

$* * \mathrm{p}<0.05, * *$ shows the significance level when $\mathrm{p}$ value is $<0.05$

The R square value was calculated to express the total amount of variance of the dependent variable, which can be accounted for by the set of independent variables (George \& Mallery, 2003). The F statistic indicates the level of statistical significance of the relationship between the set of independent variables and the dependent variable. Beta weight helps to identify the strength, direction, and statistical significance of the relationship between dependent variable and contributions of each of independent variables (George \& Mallery, 2003). The overall results of the multiple regression analysis yielded a $\mathrm{R}$ square value of .674 indicating that this set of dependent variables accounted for $67.4 \%$ of the variance of the dependent variable, leaving 32.6 per cent of the variance unaccounted for due to other variables which are not part of this model. The F statistic of 24.236 also indicates that there are statistically significant relationships between the dependent variable and the set of independent variables (predictor variables) $(\mathrm{p}=0.001 * *)$. The independent variables, social 
structure and culture $(B=-0.451, \mathrm{p}=0.002)$, gender inequality $(B=0.466, \mathrm{p}=0.021)$ and gaining social capital $(B=0.411, p=.002)$ had a significant effect on the dependent variable and these variables were found to be statistically significant.

The relationship between career supports through various strategies/initiatives offered by the organization and social structure and culture, and gender inequality even though significant, was in a direction opposite from what was predicted. It clearly indicates that in spite of the presence of various company strategies/initiatives/policies related to women manager's career advancement, the difficulties women experience due to the structural and cultural barriers and gender inequality still exist. "Male dominated culture" as cited by many researchers are still imbued with masculine values especially at the higher managerial levels. It appears that the culture is still in alignment with men's styles and leadership skill requirements for men and women are different. As Eagly andCarli (2007) rightly introduced the term "Labyrinth", both the subtle and obvious barriers with the continuing age, become more surmountable. This is the highlight of the entire universe of discussions through various researches across the globe reporting the disadvantages women experience at various stages of their career life cycle.

However, one of the factors "gaining social capital" also shows significant relationship with company strategies as indicated above and the relationship is positive. The various strategies adopted by the participating hotels such as development programs, networks, mentoring and high visibility assignments have helped the women managers to bond themselves within their organizations and beyond. This human capital allows competent work as well as knowledge, trust and shared understanding among managers.

The "gender stereotyping" and "double bind" did not show any significant relationship with the company strategies. When we look at the construct of these factors, the findings indicate that women managers are experiencing job demands to a greater extent than male managers and at the same time they are learning more from their experiences.

\subsection{Significant barriers to women's leadership}

A list of significant barriers as identified by ILO (2015) from the global report on women in business and management was the last part of the questionnaire. This set of statements were based on the most recent statistics and information by ILO at a global level which aims to create a better understanding of the barriers to women's advancement in business and management. It was a survey of around 1300 private companies across 39 developing countries. The managers were asked to rank what they considered the most significant barriers in the order of priority. 
Table 6: Significant barriers to career advancement

\begin{tabular}{|c|c|c|}
\hline Barriers & Mean & $\begin{array}{l}\text { Rank } \\
\text { order }\end{array}$ \\
\hline Roles assigned by society to men and women & 6.74 & 4 \\
\hline Women with insufficient general or line management experience & 4.14 & 14 \\
\hline Lack of leadership training for women & 10.21 & 15 \\
\hline Women have more family responsibilities than men & 3.92 & 1 \\
\hline Masculine corporate culture & 6.92 & 5 \\
\hline Lack of company equality policies and programs & 9.35 & 11 \\
\hline Stereotypes against women & 6.35 & 3 \\
\hline Inherent gender bias in recruitment and promotion & 8.42 & 7 \\
\hline Gender equality policies in place but not implemented & 8.42 & 9 \\
\hline Inadequate labour and non-discrimination laws & 9.35 & 13 \\
\hline Lack of flexible work solutions & 4.14 & 2 \\
\hline Lack of strategies for retention of skilled women & 9.14 & 10 \\
\hline Men not encouraged to take leave for family responsibilities & 7.14 & 6 \\
\hline Few roles models for women & 9.21 & 12 \\
\hline Management is generally viewed as a man's job & 7.81 & 8 \\
\hline
\end{tabular}

"Women have more family responsibilities than men" - sounds like a catchphrase. The ILO ranking may mask some of the regional differences; nevertheless the top most barriers remain the same worldwide including Indian hotel industry. The second most significant barrier as per ILO is "roles assigned by society to men and women" and the respondents of this study have ranked it as fourth. The second most significant barrier as per the study "lack of flexible work solutions" is ranked 10 as per ILO but the report mentioned that it is one of the top barriers (No.6 \& No. 2) in Asian and Caribbean countries. From the results of company policies/strategies, it was already brought out that most of the hotel companies 
$(66.7 \%)$ do not have provisions for flexible work practices. The third most important barrier "stereotypes against women" is a concern. A 1995 survey of 461 female executive of fortune 1000 companies revealed that the top most barrier for women's ascension to top leadership positions is "male stereotyping and preconceptions about women"(Catalyst, 1999). Does it mean that women managers are still apprehensive about the gender differences and, subtle and invisible barriers that are affecting their career advancement? Hopefully, further research in this area will shed light into this all pervasive phenomenon.

\section{Conclusion}

The organizational culture of hotel industry in India has not changed substantially over a period of time as observed by the researcher. The embedded norm of male dominated long hour's culture along with moderate pay packages generally discourages female students when they enter the industry for internships. The Gen Y interns consider this as just a requirement of the organization and they perceive that these long hours are unconnected with productivity. Many of them do not like the culture that they experience for six months during internship, and this becomes a bottleneck in their decision to either joining the industry or to have a long career with the industry. This negative perception that the hotel industry has received relative to other service sectors restricts the influx of women into the industry. The generation $\mathrm{Y}$ women enter labor market expecting a liner career path with good pay, also expects good social and personal life which the industry at this point in time still not able to provide. This results in increasing concern among the recruiters, to recruit and retain female talents in the future for better economic and social climate. The findings from this research is very meaningful for the decision makers as the industry consists of manpower which is quite young and dynamic and it is the responsibility of these decision makers to retain the young talent.

The output of the study may be used by the educators and industry professionals for assessing the reasons and identifying solutions to improve the processes which in turn will assist women managers to progress professionally. This mutual understanding is definitely beneficial for better organizational climate, job satisfaction and reduced turnover rates and last but not the least, better representation of women in the industry. The researcher hopes that the study outcomes contribute to the hotel industry to understand some of the vital concerns related to the career life of women. Given the potential shortage of qualified and experienced women managers in Indian industry, companies could be losing a valuable source of managers if women talent is not fully utilized. It is not fait to make women wait all their lives hoping for something to emerge out of a mirage and quench their thirst for fulfillment and accomplishment. The findings in this study need to be carefully considered if gender issues at work are to be addressed seriously as they are the viewpoints of some of the important decision makers in the industry. Although the suggestions are sound, complementary changes in management practices are needed to reduce the gap between vertical and horizontal sex segregation in Indian hotel industry.

\section{Implications of the Study}




\section{MInstitute Macrothink $_{\text {Int }}$}

International Journal of Human Resource Studies ISSN 2162-3058

This paper reflects some current realities of career life for women managers in Indian five star hotels. This was evidenced by some of the policy makers and implementers that the perceptions and experiences of women managers were less positive and linked to social roles assumed by them. These perceptions have implications for practice because organizations have to find ways to leverage the talents women are yet to bring to their professional roles. One way of being responsive is to strive to create a climate in support of women by integrating work-life balance policies and to provide an opportunity to voice their recommendations. Commitment from the corporate management will create perceptions of fairness among managers and will have meaningful impact on job and career satisfaction. The strengths and weaknesses of existing policies and practices have to be uncovered to eradicate the prejudices and to facilitate the advancement of women.

\section{References}

Accor Hotels. (2013). The Accor group's professional women's network already has 1500 members.

http://www.accorhotels-group.com/fileadmin/user_upload/Contenus_Accor/Presse/Pressrelea ses/2013/EN/121213_pr_waag_1st_anniversary_en.pdf. Accessed the 15 June, 2015, at $10: 50$

Adams, C. (2004). Mentoring and Glass Ceiling: A thesis (Master's thesis). Retrieved from ProQuest, UMI Microform, 1418622.

Apospori, E., Nikandrou, I., \&Panayotopoulou, L. (2006). Mentoring and women's career advancement in Greece. Career Development International, 9(4), 509-527.

Appelbaum, S., Audet, L. \& Miller, J. (2003). Gender and leadership? Leadership and gender? A journey through the landscape of theories. Leadership and Organization Development Journal, 24(12), 43-51.

Bajdo, L. M., \& Dickson, M. W. (2001), Perceptions of organizational culture and women's advancement in organizations: A cross-cultural examination. Sex Roles, 45(5), 399-414.

Baum, T. (2013). International perspectives on women and work in hotels, catering and tourism. Bureau for Gender Equality (No.289). Working Paper 1/2013, Sectoral Activities Department Working Paper.

Baum, T. (2015). Women in Tourism and Hospitality: Unlocking the potential in the Talent Pool. Hospitality Industry Pipeline: Diageo White Paper Series. file:///C:/Users/ACER/Downloads/Women_in_Hospitality__Tourism_White_Paper.pdf. Accessed 17 June 2015, at 11:00

Blayney, C., \&Blotnicky, K. (2010). The impact of gender on career paths and management capability in the hotel industry in Canada. Journal of Human Resources in Hospitality and Tourism, 9 (1), 233-255.

Boone, J. et al. (2013). Rethinking a glass ceiling in the hospitality industry. Cornell Hospitality Quarterly, 54(3), 230-239. 


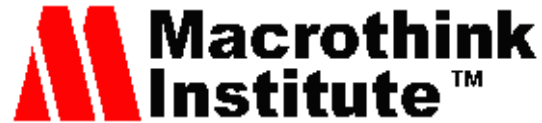

International Journal of Human Resource Studies

ISSN 2162-3058

Broadbridge, A. (2008). Barriers to ascension to senior management positions in retailing. The Service Industries Journal, 28 (9), 1225-1245.

Brownell, J (1994). Women in hospitality management: general managers' perceptions of factors related to career development. International Journal of Hospitality Management, 13(2), 101-117.

Brownell, J. (1994). Personality and career development: A study of gender differences. Cornell Hotel and Restaurant Administration Quarterly. 35(2),. 36-47.

Burke, R. J. (2002). Career development of managerial women. Advancing women's careers, Oxford: Blackwell, pp. 139-161.

Burke, R.J. (2006), Organizational practices supporting women's career advancement and their satisfaction and well-being in Turkey. Women in Management Review, 2(8), 610-624.

Carter, N.M., \& Silva, C. (2010). Women in management: Delusions of progress. Harvard Review. Retrieved from https://hbr.org/2010/03/women-in-management-delusions-of-progress/ar/1.

Catalyst (2012). Women in the labor force in India. Retrieved from http://www.catalyst.org/knowledge/women-labour-force-india.

Catalyst (2014). Catalyst study reveals India's "High Potential" women in technology aim high but earn less, get fewer opportunities for advancement than men. Retrieved from http://www.catalyst.org/media/catalyst-study-reveals-indias-high-potential-women-technolog y-aim-high-earn-less-get-fewer.

Centre for Social Research (2010). Women managers in India: Challenges and opportunities. Retrieved from http://womenleadership.in/Csr/Women-Managers-In-India.pdf.

Chaudhary, M., \& Gupta, M. (2010). Gender Equality in Indian Hotel Industry - A study of Perception of Male and Female Employees. International Journal of Hospitality and Tourism Systems, 3(1), 31-41.

Chaudhary, M., \& Gupta, M. (2011). Gender sensitivity in Indian hotel industry - A study of selected hotels. Tourism Development Journal, 9(1), 61-75.

Chen, J. J. (2007). Ordinary vs. extraordinary: Differential reactions to men's and women's pro-social behavior in the workplace (Unpublished doctoral dissertation).

Chen, Y.C. (2011). A study of hotel managers'job satisfaction-Based on the view Point of career development. Retrieved from http://ttqs.wda.gov.tw/Column_Files/Viewpoint\%20of\%20Career\%20Development--final.pdf Clerk, J. (2014). Women in Hospitality and Tourism: The Asian Opportunity. International New York Times. from http://www.salabai.com/documents/Diageo\%20Women\%20in\%20Hospitality\%20and\%20To urism\%20INYT\%20Supplement\%2026022014.pdf. 


\section{Al Macrothink}

International Journal of Human Resource Studies

ISSN 2162-3058

2016, Vol. 6, No. 2

Coder, L.A., \& Spiller, M.S. (2013). Leadership education and gender roles: think manager, think male?.Retrieved from http://go.galegroup.com/ps/i.do?id=GALE\%7CA332788071\&v=2.1\&u=4104mtnla\&it=r\&in $\mathrm{PS}=$ true $\&$ prodId $=\mathrm{PROF} \&$ userGroupName $=4104 \mathrm{mtnla} \& \mathrm{p}=\mathrm{PROF} \&$ digest $=9 \mathrm{a} 0 \mathrm{f} 1 \mathrm{~b} 7 \mathrm{adb} 7100$ 6c47458339479d277\&rssr=rss.

Comrey, A. \& Lee, H. (1992). A first course in factor analysis. (2 ${ }^{\text {nd }}$ Ed.). Hillsdale: Lawrence Erlbaum Associates.

Culpan, O., \& Wright, G.H. (2002). Women abroad: Getting the best results from women managers. International Journal of Human Resource Management, 13(5), 784-801.

Doherty, L. (2004). Work-Life Balance Initiatives: Implications for Women. Employee Relations, 26(4), 433-452.

Duehr, E,E. \& Bono, J.E. (2006). Men, Women and Managers: Are Stereotypes finally changing? Personnel Psychology, 59, 815-846.

Eagly, A.H., \&Carli, L.L. (2007). Through the labyrinth. Boston: Harvard University Press.

Ezeedeen, S.R., \& Ritchey, K.G. (2009). Career advancement of family balance strategies of executive women. Gender in Management: An International Journal, 2(6), 388-411.

George, D., \&Mallery, P. (2003). SPSS for windows step by step: A sample guide and reference. Boston: Allyn\& Bacon.

Gregg, J.B. \& Johnson, P.M. (1990). Perceptions of discrimination among women as managers in hospitality organizations. FIU Hospitality Review, Vol. 10, No. 22.

HVS (2012). Indian hotel industry survey 2011-12. Retrieved from file://C:/Users/ACER/Downloads/HVS\%20 \%20Indian\%20Hotel\%20Industry\%20Survey\% 202011-2012.pdf. Accessed 15 July 2015, at 11:00

HVS (2014). Hotels in India: Trends and opportunities. Retrieved from http://www.hvs.com/article/7041/2014-hotels-in-india-trends-opportunities/.

Ibarra, H., Carter, N.M., Silva, C. (2010). Why Men Still Get More Promotions Than Women. Harvard Business Review. Retrieved from (https://hbr.org/2010/09/why-men-still-get-more-promotions-than-women).

International Labor Organization. (2015). Women in Business Management: Gaining Momentum. Retrieved from http://www.ilo.org/wcmsp5/groups/public/---dgreports/---dcomm/---publ/documents/publicati on/wcms_334882.pdf.

ITC to double proportion of women employees to 30 pc. (2013, April 16). The Economic Times. Retrieved from Retrieved from http://articles.economictimes.indiatimes. com/2013-04-16/news/38586688_1_itc-maurya-women-employees-itc-rajputana

Kattara, H. (2005). Career challenges for female managers in egyptian hotels. International 
Journal of Contemporary Hospitality Management, 17(1), 238-255.

Knutson, B.J., \&Schmidgall, R.S., (1999). Dimensions of the glass ceiling in the hospitality industry. Cornell Hotel and Restaurant Administration Quarterly, 64-75.

Kumar, A. (2014). An investigation of the perception of hospitality graduates towards the industry: A gender perspective. African Journal of Hospitality \& Leisure, 3(2).

Ladkin, A. (2002). Career analysis: A case study of hotel general managers in Australia. Tourism Management, 23(4), 379-388.

Linehan, M. (2002). Networking for female managers 'career development: empirical evidence. Journal of Management Development, 20(10), 823-829.

Loutfi, M.F. (2001). Women, gender and work. Retrieved from International Labor Organization websitehttp://www. iiav.nl/ epublications/ 2001/ women_gender_and_work.pdf

Mattis, M.C. (2002). Best practices for retaining and advancing women professionals and managers. In R.J. Burke \& D.L. Nelson (Eds.). Advancing women's careers. Oxford, UK: Basil Blackwell.

McKinsey \& Company (2012, June). Women Matter: An Asian perspective: Harnessing female talent to raise corporate performance. Retrieved from file:///C:/Users/ACER/Downloads/Women_Matter_An_Asian_perspective.pdf.

Menon, M. (2013, August 13). Now for an old girl's club. The Hindu. Retrieved from http:// www.thehindu.com/ features/ the-yin-thing/ now-for-an-old-girls-club/article5018494.ece

Miller, C.C., Glick, W.H., \& Cardinal, L.B. (2005). The allocation of prestigious positions in organizational science: Accumulative advantage, sponsored mobility, and contest mobility. Journal of Organizational Behavior, 26(5), 489-516.

Mooney, S. (2007). Where is she? A Female Manager's Place in Australian and New Zealand Hotels. Retrieved from http://aut.researchgateway.ac.nz/handle/10292/216.

NDTV Business. (2014, September 20). Only Five Percent Indian Women in Senior Corporate Posts: Study. Retrieved from http://www.ndtv.com/india-news/only-five-percent-indian-women-in-senior-corporate-posts-s tudy-668627).

Nath, D. (2000). Gently shattering the glass ceiling: Experiences of Indian women managers. Women in Management Review, 15(1), 44-5.

Neil, A. (2007). Women mentoring women: Tapping the wisdom tapping the wisdom in networks to navigate career obstacles and opportunities Retrieved from www.interscience.wiley.com.

Ng. C.W. \& Pine, R. (2003). Women and men in hotel management in Hong Kong: Perceptions of gender and career development issues. International Journal of Hospitality 
Management, 22(1), 85-102.

Nzioka, A.M. (2013). Hotel general managers' perception of factors related to women career progression in the hospitality industry at the coast region of Kenya. (Doctoral thesis). Retrieved from http://ir library.ku.ac.ke/bitstream/handle/123456789/9220/Nzioka,\%20Alice\%20Mueni.pdf?sequenc $\mathrm{e}=3$.

Omotayo, O.A., Esther, O.A. \&Ibiyinka, O.S. (2014). Career development as a determinant of organizational growth: Modelling the relationship between these constructs in the Nigerian banking industry. American International Journal of Social Science, 3(7), 67-76.

Panwar, S., et al. (2012). High Staff Turn Over In Hotel Industry, Due To Low Remunerations And Extended Working Hours!.VSRD International Journal of Business \& Management Research, 2(3).

Powell, G. (2000). The glass ceiling: Explaining the good and bad news. In M. Davidson \& R. Burke (Eds.), Women in management: Current research issues volume II. 237-250. London: Sage Publications. doi: http://dx.doi.org/10.4135/9781446219775.n16

Singh, A., et al. (2011). Women in Hospitality Industry: Can women reach the top breaking though Glass Ceiling in Management.Retrieved from http://sarjiwanpublications.blogspot.in/2011/02/women-in-hospitality-industry-can-women.ht $\mathrm{m}$.

Sodhi, J. (2008). Women on top: Charging ahead with grace. Retrieved from http://www.hospitalitybizindia.com/detailNews.aspx?aid=1385\&sid=5.

Sposito, C.A. (2013). Career barriers for women executives and the glass ceiling syndrome: The case study comparison between French and Turkish women executives. Procedia-social and behavioral sciences, 75(1), 488-497.

Subramaniam, D. (2014). Situational Analysis of Graduate Working Women in Selected Sectors of Commercial Hospitality Industry.Retrieved from http://shodhganga.inflibnet.ac.in/handle/10603/34320.

Swanson, J.L. \&Toker. D.M. (1991). College students' perception of barriers to career development. Journal of vocational behavior. 38(1), 90-106.

Swanson, J.L. \&Woitke, M.B. (1997). Theory into practice in career assessment for women: Assessment and interventions regarding perceived career barriers. Journal of career assessment, 5(4), 443-462.

The flight from marriage. (2011, August 20). The Economist. Retrieved from http://www.economist.com/node/21526329.

Tlaiss, H. \& Kauser, S. (2010). Perceived organizational barriers to women's career advancement in Lebanon. Gender in Management: An International Journal, 25(6), 462 496. 


\section{Macrothink}

International Journal of Human Resource Studies

ISSN 2162-3058 2016, Vol. 6, No. 2

Walsh, K., Fleming, S., \&Enz, C.A. (2014). Female executives in hospitality: Reflections on career journeys and reaching the top. Cornell Hospitality Reports, 14(4), 6-17.

Woods, R.H., \&Viehland, D. (2000). Women in Hotel Management: Gradual progress, uncertain prospects. Cornell Hotel and Restaurant Administration Quarterly, 51-54.

Zhong, Y. (2006). Factors affecting women's career advancement in the hospitality industry: Perceptions of students, educators and industry recruiters (Doctoral thesis). Retrieved from https://repositories.tdl.org/ttu-ir/bitstream/handle/2346/11540/Zhong_Yan_diss.pdf?sequence $=1$

\section{Notes:}

1. This research focuses entirely on five star hotels in India and other categories of hotels are not taken into consideration and out of the scope of this study. Hence research results cannot be generalized.

2. Most of the hotels included in the study are from Delhi and Mumbai due to dense population of five star hotel categories in these cities.

3. The opinions of the participant managers are purely from the professional perspective and based on the current work environment prevailing in Indian five star hotels.

\section{Copyright Disclaimer}

Copyright for this article is retained by the author(s), with first publication rights granted to the journal.

This is an open-access article distributed under the terms and conditions of the Creative Commons Attribution license (http://creativecommons.org/licenses/by/3.0/). 